\title{
Rancangan Aplikasi Pembelajaran Rumus Trigonometri Berbasis
}

\author{
Wanti Rahayu ${ }^{1}$, \& Ari Irawan ${ }^{2 *}$ \\ ${ }^{1,2}$ Universitas Indraprasta PGRI, Jakarta, Indonesia
}

\section{INFO ARTICLES}

Article History:

Received: 24-09-2020

Revised: $10-12-2020$

Approved: 18-12-2020

Publish Online: 25-12-2020

\section{Key Words:}

Trigonometry; Android Aplication; Virtual Learning;

\section{(†) (2)}

This article is licensed under a Creative Commons AttributionShareAlike 4.0 International License.

\begin{abstract}
This study aims to create a learning application for trigonometric formulas. The method used in this research is RnD (Research and Development) with the ADDIE model (analysis, design, development, implementation and evaluation). At this time, this research is only at the design stage which means that the researcher only creates a screen display design that will later be presented on the application. The screen design will be consulted with material experts which consists of mathematics teachers, screen display design experts and experts of educational technology field. The result of this study is in a design form of application screen display that will later be created with the advices from experts before the system is developed and implemented in the learning application design that has been made.
\end{abstract}

\begin{abstract}
Abstrak: Penelitian ini bertujuan untuk merancang aplikasi pembelajaran rumus-rumus trigonometri. Metode yang digunakan dalam penelitian ini adalah penelitian pengembangan $\mathrm{RnD}$ (Reseach and Development) dengan model ADDIE (Analysis, Design, Development, Implementation and Evaluation). Saat ini penelitian ini hanya baru sampai tahapan desain artinya ini hanya bru memembuat tampilan dan rancangan layar yang akan di tampilkan pada aplikasi. Rancangan layar ini nantinya akan dikonsultasikan dengan pakar materi yaitu guru matematika, pakar desain tampilan layer dan juga pakar di bidang teknologi pendidikan dan juga pakar materi yaitu guru mata pelajaran matematika. Hasil dari penelitian ini yaitu berupa rancangan tampilan layar aplikasi yang nantinya akan dibuat kemudian dikonsultasikan dengan para pakar sebelum dilakukan pengembangan sistem dan implementasi dari rancangan aplikasi pembelajaran yang telah dibuat.
\end{abstract}

Correspondence Address: Jalan Raya Tengah, Kelurahan Gedong Kec. Pasar Rebo, Jakarta Timur; e-mail: ari_irawan@unindra.ac.id

How to Cite (APA 6 ${ }^{\text {th }}$ Style): Rahayu, W., \& Irawan, A. (2020). Rancangan Aplikasi Pembelajaran Rumus Trigonometri Berbasis Android. JKPM (Jurnal Kajian Pendidikan Matematika), 6(1): 49-56.

Copyright: 2020 Wanti Rahayu, Ari Irawan

Competing Interests Disclosures: The authors declare that they have no significant competing financial, professional or personal interests that might have influenced the performance or presentation of the work described in this manuscript. 


\section{PENDAHULUAN}

Dampak dari pandemic covid-19 menyebabkan perubahan kebiasaan dari berbagai sektor baik sosial, ekonomi, kesatan dan pendidikan. Upaya mencegah dan memutus mata rantai dari pandemic ini adalah dengan menghindari pertemuan secara langsung dan diganti secara virtual. Perkembangan teknologi yang sangat pesat menghasilkan hal-hal baru, baik secara umum maupun teknologi perkembangan teknologi dalam dunia pendidikan (Fauziah et al., 2016). Artinya sektor pendidikan harus siap meghadapi perubahan ini maka perlu adanya strategi yang tepat dan inovasi teknologi di bidang pendidikan. Pelajar dapat menggunakan teknologi digital untuk kegiatan pembelajaran seperti membaca dan mengirim email, mengakses sistem manajemen pembelajaran, membaca jurnal atau e-book, melakukan kuis secara daring, berpartisipasi dalam forum diskusi, dan sebagainya. Atas dasar tersebut, pembelajaran daring (e-learning) dapat menjadi salah satu cara dalam melaksanakan pembelajaran jarak jauh di tengah pandemic covid-19 ini (Nahdi \& Jatisunda, 2020).

Pentingnya konsep matematika akan memberikan kemudahan siswa untuk memahami masalah, merancang strategi penyelesaian, dan menyelesaikan masalah secara terstruktur dan tersistematis (Farhan \& Zulkarnain, 2019). Guru sebagai panutan hendaknya dapat memberikan contoh kongkret pembelaaran matematika sehingga siswa dapat dengan baik mencerna, menerima dan mengaplikasikan matematika dalam kehidupan sehari-hari. Guru seharusnya tidak hanya memberikan pengetahuan akan tetapi siswa hendaknya secara aktif membangun pengetahuan dalam pikiran mereka sendiri (Misdalina et. al., 2009). Sehingga guru diharapkan akan dapat memberikan pembelajaran yang bermakna kepada siswa. Matematika berfungsi mengembangkan kemampuan menghitung, mengukur, menurunkan dan menggunakan rumus matematika yang diperlukan dalam kehidupan sehari-hari melalui materi pengukuran, geometri, aljabar, statistika, kalkulus dan peluang, trigonometri. Selain itu matematika juga berfungsi mengembangkan kemampuan mengkomunikasikan gagasan melalui model matematika, diagram, grafik atau tabel (Zulkardi \& Darmawijoyo, n.d.). Berdasarkan pendapat tersebut memang ilmu matematika sangat luas cakupanya. Sudah sejak lama siswa dihadapkan pada kesulitan mempelajari materi trigononmetri, apalagi saat ini menjadi tantangan bagi guru menyajikan pembelajaran bagi siswa dalam bentuk kelas virtual untuk materi trigonometri menjadi bagian yang cukup sulit. Oleh sebab itu perlu adanya solusi untuk menyajikan pembelajaran materi trigonometri untuk dapat lebih mudah dan dipahami oleh siswa.

Kesulitan yang dihadapi siswa saat ini menjadi inspirasi bagi penulis untuk membuat apliksi pembelajaran matenmatika tentang trigonometri, hal ini melihat dari berbagai hasil riset sebelmnya Mata pelajaran Matematika, khususnya trigonometri adalah salah satu mata pelajaran sekolah yang sangat sedikit disukai dan hanya sebagian siswa yang berhasil dalam belajar trigonometri, hanya siswa yang mempunyai keyakinan yang baik terhadap trigonometri yang berhasil (Jatisunda \& Nahdi, 2019). Tujuan dari membuat aplikasi ini adalah untuk memudahkan siswa dalam mengetahui rumus-rumus yang berkaitan dengan trigonometri. Fungsi dan manfaat trigonometri dalam kehidupan sehari-hari harus dapat dirasakan oleh siswa sehingga siswa dapat bersemangat dalam mempelajarari matematika. Pengelolaan pembelajaran untuk materi ajar trigonometri di lapangan masih banyak dijumpai berbagai kesulitan dan kendala, baik dari segi pengelolaan pembelajaran dari guru maupun dari sisi pemahaman siswa (Rosdian, 2016). Maka dari itu menjadi penting membuat aplikasi pembelajaran yang dapat memudahkan siswa dalam memahami materi trigonometri. Ini merupakan bagian dari inovasi pembelajaran matematika yang dilakukan saat pandemic covid-19 yang belangsung saat ini, artinya pembelajaran yang serba dilakukan secara virtual dapat terbantu dengan adanya berbagai riset yang berkaitan dengan perancangan dan program pembuatan aplikasi pembelajaran yang dapat secara langsung digunakan oleh siswa saat ini. 


\section{METODE}

Peneliti melakukan riset untuk tujuan akhirnya adalah membuat aplikasi pembelajaran matematika untuk materi trigonometri, dalam proses penelitian saat ini tim peneliti baru pada tahapan desain tampilan layer aplikasi yang akan dikembangkan. Penelitian Reseach and Development adalah metode penelitian yang digunakan untuk menghasilkan produk tertentu dengan menguji keefektifan produk tersebut. Penelitian $\mathrm{RnD}$ (Reseach and Development) merupakan metode penelitian yang digunakan untuk mengembangkan atau memvalidasi produk-produk yang digunakan dalam pendidikan dan pembelajaran (Hartati et al., 2017). Model yang digunakan dalam penelitian ini adalah model ADDIE yaitu analysis, design, development, implementation dan evaluation. Model pengembangan ADDIE merupakan suatu model dalam mendesain suatu perangkat pendidikan yang terbagi dalam 5 fase, yaitu:1) Fase Analisis, 2) Fase Desain, 3) Fase Pengembangan, 4) Fase Implementasi 5) Fase Evaluasi (Suwito \& Trapsilasiwi, 2016). Tahapan yang telah tim peneliti lakukan saat ini baru pada tahapan design, karena keterbatasan peneliti artinya desain aplikasi yang akan dibuat akan dikonsultasikan kepada para pakar yang terdiri dari pakar teknologi pendidikan, pakar materi yaitu guru matematika. Desain penelitian dan pengembangan yang digunakan dimodifikasi sesuai kebutuhan. Pada tahap studi pendahuluan terdapat studi kepustakaan, survei lapangan, dan penyusunan draf produk yang dilanjutkan dengan telaah draft produk, penyempurnaan produk, dan validasi produk. Kemudian pada tahap pengembangan dilakukan uji coba terbatas.

\section{HASIL}

Hasil dari penelitian ini berupa apliksi pembelajaran matematika tentang rumus trigonometri berbasis android. Tahapan yang telah dilakukan tim peneliti yaitu analisis dan desain rumus trigonometri yang akan dibuat aplikasinya berbasis andoid. Penelitian ini menggunakan metode ADDIE (sampai pada tahap desain) yang digunakan sebagai pengembangan pembelajaran rumus trigonometri berbasis android.

1. Tahapan analisis

Tahapan analisis yang dilakukan tim peneliti yaitu melakukan study awal tentang bagaimana siswa melakukan kegiatan pembelajaran tentang rumus-rumus trigonometri. Penelitian ini dilakukan beberapa survey ke beberapa siswa SMP dan SMA terkait kendala yang dihadapi siswa dalam mempelajari matematika terutama pada materi trigonometri. Tim juga melakukan wawancara dan observasi pada guruguru SMP dan SMA terkait kendala yang dihadapi ketika mengajarkan rumus-rumus trigonometri pada siswa. Hasil observasi tersaji pada Tabel 1. Rata-rata pada siswa SMP dan SMA hampir sama dalam mengalami kendala dan kesulitan mempelajari trigonometri.

\section{Tabel 1. Kendala yang Dihadapi oleh Guru dan Siswa}

Guru

Materi yang cukup sulit dan abstrak bagi siswa sehingga kesulitan dalam mengajarkannya.

Tingkat kemampuan siswa dalam mengahafal rumus-rumus trigonometri

Sulit bagi siswa untuk menurunkan rumus trigonometri dari satu rumus ke rumus lainnya.

Pemahaman yang belum maksimal terhadap materi trigonometri sehingga sulit diterapkan ke dalam materi lain misalnya integral
Siswa merasa tidak ada gunanya belajar trigonometri.

Siswa merasa kurang maksimal dalam menghafal rumus-rumus

Siswa merasa tidak merasakan manfaat dari belajar trigonometri dalam kehidupan sehari-hari. Siswa masih tumpang tindih dari materi satu ke materi lainnya dalam mempelajari trigonometri. 


\begin{tabular}{|c|c|}
\hline Guru & Siswa \\
\hline $\begin{array}{l}\text { trigonometri, limit trigonometri ataupun } \\
\text { aplikasi penggunaan rumus trigonometri }\end{array}$ & \\
\hline
\end{tabular}

2. Tahapan desain

Tahapan ini tim peneliti melakukan beberapa desain atai merancang tampilan layer berdasarkan tahapan analisis permasalah yang dihadapi oleh guru dan siswa dalam mempelajari materi trigonometri. Tim melakukan desain aplikasi tampilan layer tentang rumus-rumus terkait pembelajaran trigonometri. Terdapat beberapa desain tampilan layar yang peneliti desain pada apliksi yang akan dibuat dengan beberapa pertimbangan seperti materi rumus yang digunakan/diperlukan untuk siswa SMP dan SMA karena terget dari pada calon pengguna aplikasi pembelajaran ini adalah siswa SMP dan SMA. Berikut beberapa tampilan layar yang didesain oleh tim peneliti tersaji dalam Gambar 1., Gambar 2., Gambar 3., Gambar 4., dan Gambar 5.

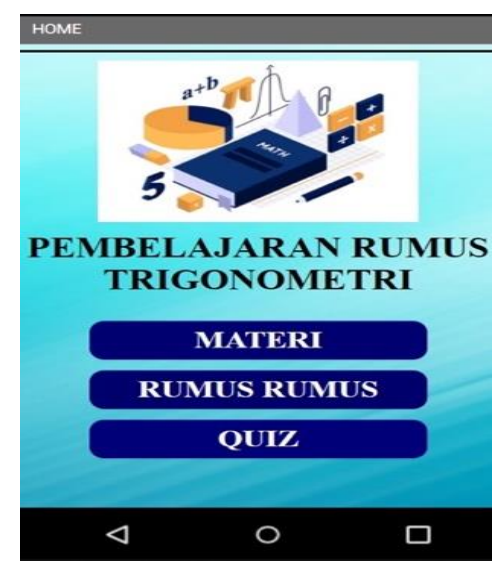

\section{Gambar 1. Tampilan Menu Home}

Pada Gambar 1. telihat tampilan awal bagian depan "home" yang ketika mengunduh aplikasi dan melakukan pembukaan aplikasi pertama kali akan muncul menu home. Di menu home ada beberapa petunjuk atau tombol yang digunakan untuk melanjutkan lebih dalam ke dalam aplikasi yaitu materi, rumus dan quiz. Untuk materi dan soal yang disajikan nantinya secara umum saja yang memang dipelajari pada saat SMP dan SMA.

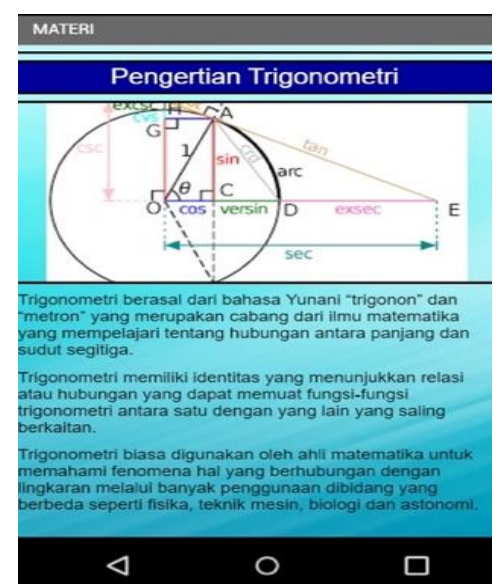

Gambar 2. Tampilan Pengertian Trigonometri 
Tampilan Gambar 2. terlihat sekilas materi tentang trigonometri. Sedikit penjelasan tentang trigonometri dan kegunaan trigonometri. Dan tersaji gambar salah satu contoh penggunaan trigonometri dalam penyelesaian lingkaran.

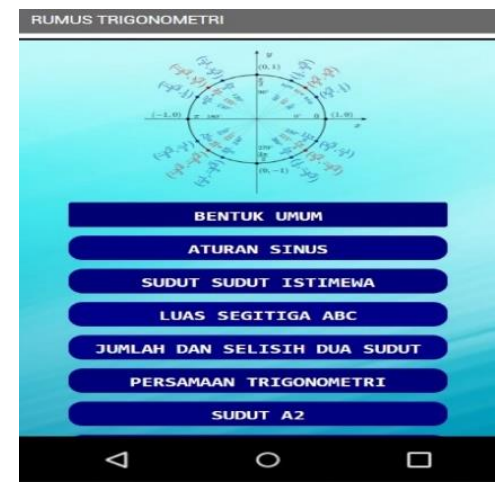

Gambar 3: Tampilan menu

Tampilan pada Gambar 3. akan muncul ketika kita klik tombol rumus-rumus pada menu home. Dalam tampilan menu rumus-rumus maka akan telihat pembagian beberapa rumus trigonometri yaitu: bentuk umum trigonometri, aturan sinus, sudut-sudut istimewa, luas segitiga, jumlah dan selisih dua sudut, persaman sudut trigonometri dan sudut $\alpha^{2}$.

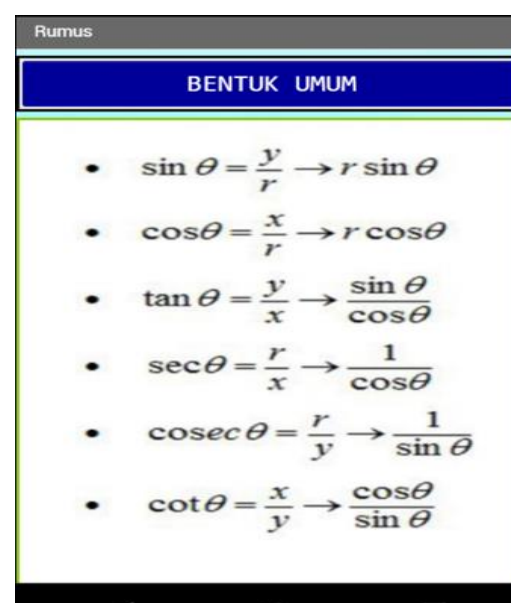

$\triangleleft$
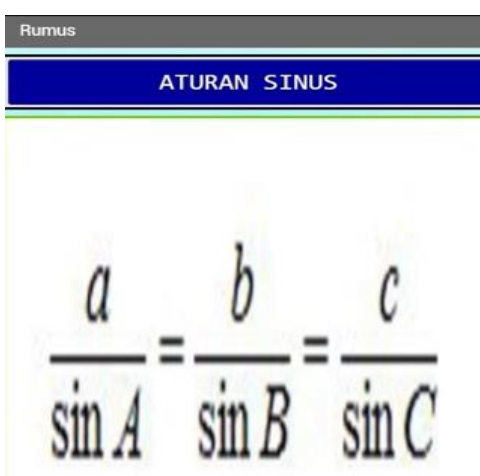

$\triangleleft$

$\square$

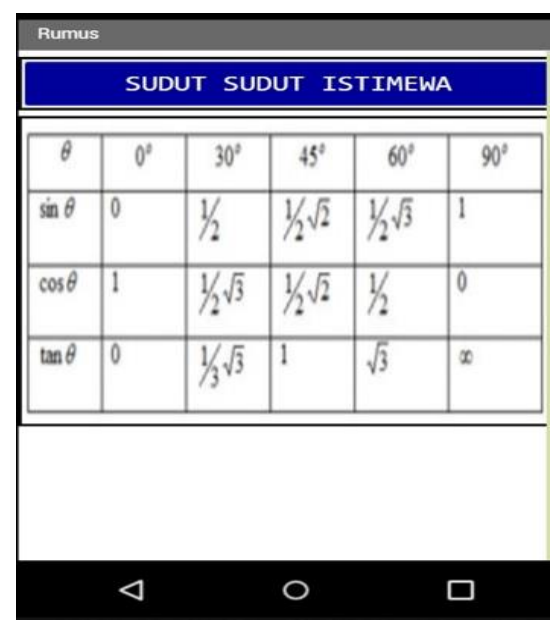

\section{Gambar 4. Tampilan Rumus Bentuk Umum Trigometri}

Pada Gambar 4. terlihat materi-materi yang berisi rumus-rumus trigonometri. Bentuk umum dari trigononometri, aturan sinus dan sudut istimewa pada trigonometri beserta nilainya. Ini hanya beberapa contoh tampilan yang nantinya akan tampil pada aplikasi pembelajaran matematika yang berkaitan dengan rumus trigonometri. Ada banyak menu dan rumus yang akan ditampilkan nantinya. 


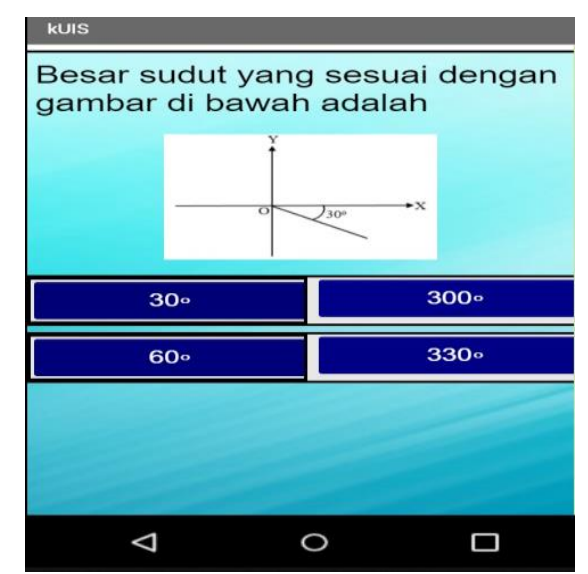

Gambar 5. Tampilan Kuis

Tampilan Gambar 5. merupakan salah satu contoh tampilan menu pada kuis. Pertanyaan-pertanyaan yang digunakan untuk kuis nantinya adalah pertanyaan berupa pilihan ganda. User nantinya akan menjawab soal-soal yang tersaji dalam pilihan ganda. Kuis ini juga dibagi menjadi beberapa sesi ada kuis 1 s.d. kuis 10 yang masing-masing kuis memuat 10 soal pilihan ganda. User nantinya akan diminta menjawab dan akan keluar skor jumlah jawaban yang dijawab benar oleh user.

\section{PEMBAHASAN}

Setelah dilakukan tahapan analisis dan desain nantinya akan dikembangkan menjadi aplikasi pembelajaran rumus trigonometri. Pada tahapan analisis ditemukan hal-hal yang menjadi fokus peneliti memang hampir semua siswa dan guru yang menjadi sumber data analisis menyatakan bahwa mempelajari dan mengajarkan materi trigonometri cukup sulit dan memakan waktu yang lama. Hal ini terlihat dari jumlah siswa yang memiliki nilai kurang pada materi trigonometri maupun materi-materi yang terkait trigonometri semisal adalah turunan dan integral bentuk trigonometri untuk tingkat sekolah menengah atas. Guru menjadi kesulitan ketika mengajarakan turunan, integral atau terkait implementasi soal lingkaran dalam segita dan luar segita yang dalam penyelesaian menggunkan rumus-rumus trigonometri yang saling keterkaitan antara aturan satu dengan lainya pada materi trigonometri.

Semakin bertambah pesat perkembangan teknologi sehingga mampu mengubah gaya hidup masyarakat sebagai pengguna teknologi (Nadun, 2017). Begitu banyak riset yang telah dikembangkan tentang aplikasi pembelajaran trigonometri, yang menjadi alasannya adalah untuk mempermudah siswa dalam mempelajari rumus-rumus trigonometri secara mandiri dan digital. Salah satu media pembelajaran yang dapat digunakan untuk mempermudah siswa mengingat rumus trigonometri yaitu media mobile learning. Mobile learning dapat dijadikan sebagai salah satu alternatif untuk memecahkan permasalahan dalam bidang pendidikan, teutama masalah pemerataan akses informasi pendidikan, kualitas konten pembelajaran yang berupa materi pembelajaran dengan bentuk teks ataupun gambar yang disertai dengan contoh soal serta peningkatan kualitas pengajar agar lebih baik dalam membuat menyampaikan materi pembelajaran dan mengelola kegiatan belajar mengajar (Sastrawati \& Novallyan, 2017). Atas dasar ini penelitian terkait pengembangan pembelajaran matematika yang berkaitan dengan trigonometri cukup banyak.

Interaksi di sekolah yang sudah sedemikian sulit ketika belajar dikelas dikarenakan efek dari pembatasan sosil berskala besar maka siswa diharapkan dapat terbantu dengan adanya aplikasi pembekajaran matematika berbasis android khusus untuk rumus-rumus trigonometri. Salah satu perubahan utama adalah kesempatan untuk membantu siswa terlibat dengan konsep trigonometri menggunakan 
teknologi, perubahan besar kedua adalah siswa dapat berinteraksi langsung dengan ide-ide trigonometri melalui media teknologi dalam cara yang lebih aktif (Akbar \& Linda, 2017).

Media pembelajaran adalah suatu bagian perantara komponen yang sangat penting untuk memaksimalkan proses pembelajaran. Penggunaan media juga berfungsi sebagai pendukung agar materi atau isi pelajaran semakin jelas dan dengan mudah dapat dikuasai oleh siswa (Sartika \& Yulita, 2019). Perlu lebih banyak media pembelajaran yang dikembangkan untuk dapat membantu siswa belajar mandiri dirumah. Siswa sudah dapat menggunakan berbagai aplikasi dan juga materi yang banyak terkait dengan materi trigonometri. Diharapkan sebelum pembelajaran dimulai siswa sudah membaca sekilas tentang rumus-rumus trigonometri sehingga pada saat pembelajaran siswa sudah mempunyai bekal metari pembelajaran, siswa dapat terbantu dengan apalikasi ini dan dapat mengukur kemampuan dirinya dengan adanya latihan soal-soal yang tersedia pada aplikasi ini.

Sudah tidak dapat dipungkiri matematika menjadi bagian pelajaran yang masih dianggap sangat sulit bagi sebagian besar siswa. Aljabar dan trigonometri memiliki dua bahan kajian yaitu Aljabar dan Trigonometri sehingga mahasiswa juga masih kesulitan dalam menyelesaikan soal pemecahan masalah (Imelda, 2018). Ini menjadi dasar riset peneliti dalam mengembangkan pembelajaran yang efektif dan efisein dalam mempelajari trigonometri. Penelitian ini memang tidak lepas dari keprihatinan peneliti terhadap rendahnya minat siswa dalam mempelajarai trigonomeri. Harapan peneliti yaitu siswa dapat memanfaatkan teknologi informasi sebagai bagian dari membantu siswa untuk tetap belajar mandiri dari rumah. Hendaknya sebelum mempelajari trigonometri siswa telah menahami konsep Phytagoras. Materi Phytagoras dalam trigonometri menjadi materi yang diajarkan sebelum masuk ke materi trigonometri (Putra \& Anggraini, 2016). Perlu adanya kemampuan awal siswa dalam mempelajari trigonometri salah satunya yang penting adalah siswa sudah memahami tentang teorema phytagoras.

Matematika merupakan salah satu pengetahuan dan disiplin ilmu yang sangat bermanfaat dalam kehidupan, baik dari materi maupun kegunaannya. Selain diperlukan untuk kehidupan sehari-hari, ilmu pengetahuan dan teknologi tidak lepas dari matematika (Lestariningrum, 2015). Diperlukan kemampuan guru untuk mengungkap kegunaan mempelajari trigonometri dalam kehidupan sehari-hari. Guru harus mampu mengungkap bagaimana trigonometri diterapkan dalam berbagai kegiatan yang berkaitan dengan siswa. Proses pengembangan pembelajaran ini menjadi bagian penting sebagai upaya untuk memfasilitasi siwa belajar mandiri secara efektif dan efisien. Pengembangan adalah proses atau cara perbuatan untuk mengembangkan suatu bahan yang akan diujikan secara bertahap dan teratur sehingga dapat menghasilkan hasil yang lebih baik (Misdalina et. al., 2009). Pada tahapan saat ini penelitian baru pada tahapan desain dan pengembangan untuk dapat berjalan di aplikasi sehingga belum dapat di uji coba. Nantinya hasil setalah tahapan ini akan diuji coba dan validasi pakar. Sehingga dihasilkan produk berupa aplikasi pembelajaran rumus trigonometri berbasis android yang siap pakai.

\section{SIMPULAN}

Bedasarkan hasil dan pembahasan yang telah disajikan, maka dapat diambil simpulan, desain yang telah dibuat untuk aplikasi pembelajaran rumus trigonometri perlu perbaikan di beberapa tampilan dan isi materi yang disampaikan. Berdasarkan masukan dari pakar materi hendaknya diberikan contoh soal dan laitihan soal interaktif dalam aplikasi yang akan diperbaiki nantinya. Aplikasi ini diharapkan dapat berguna bagi guru dan siswa dalam menunjang pembelajaran matematika dari rumah. 


\section{DAFTAR RUJUKAN}

Akbar, G., \& Linda, M. (2017). Aplikasi Pembelajaran Trigonometri Berbasis Android Menggunakan Algoritma Fisher Yates Shuffle. Jurnal Teknik Komputer, 3(2), 114-119.

Farhan, M., \& Zulkarnain, I. (2019). Analisis Kesalahan Mahasiswa pada Mata Kuliah Kalkulus Peubah Banyak Berdasarkan Newmann's Error Analysis. JKPM (Jurnal Kajian Pendidikan Matematika), 4(2), 121-134.

Fauziah, I. Z., Sutrisno, \& Suwarni. (2016). Pengembangan E-Modul Berbasis Adobe Flash CS6 pada Mata Pelajaran Penataan Barang Dagang. Jurnal Pendidikan Bisnis Dan Manajemen, 2(2), 154-159. https://doi.org/10.15713/ins.mmj.3

Hartati, S., Dewi, N. A. K., Puastuti, D., Muslihudin, M., \& Budi, N. S. (2017). Sistem Aplikasi Educhat Stmik Pringsewu Berbasis Android Sebagai Media. Teknosi, 03(01), 143-152.

Imelda, I. (2018). Analisis Kesulitan Mahasiswa Dalam Menyelesaikan Soal Pemecahan Masalah Pada Mata Kuliah Aljabar Dan Trigonometri. MES: Journal of Mathematics Education and Science, 4(1), 49-50. https://doi.org/10.30743/mes.v4i1.868

Jatisunda, M. G., \& Nahdi, D. S. (2019). Kesulitan siswa dalam memahami konsep Trigonometri dilihar dari learning obstacles. Jurnal Didactical Mathematics, 2(1), 9-16.

Lestariningrum, A. (2015). Pemanfaatan media biji-bijian sebagai sumber belajar bidang pengembangan matematika pada anak usia dini. Jurnal EFEKTOR, 26(1), 12-18.

Misdalina, Zulkardi, \& Purwoko. (2009). Pengembangan materi integral untuk sekolah menengah atas (SMA) menggunakan pendekatan pendidikan matematika realistik indonesia (PMRI) di palembang. Jurnal Pendidikan Matematika, 3(1), 61-74.

Nadun, N. (2017). Pengaruh Minat Belajar Siswa terhadap Hasil Belajar Trigonometri. JKPM (Jurnal Kajian Pendidikan Matematika), 3(1), 67. https://doi.org/10.30998/jkpm.v3i1.1969

Nahdi, D. S., \& Jatisunda, M. G. (2020). Analisis Literasi Digital Calon Guru Sd Dalam Pembelajaran Berbasis Virtual Classroom Di Masa Pandemi Covid-19. Jurnal Cakrawala Pendas, 6(2), 116-123. https://doi.org/10.31949/jcp.v6i2.2133

Putra, R. W. Y., \& Anggraini, R. (2016). Pengembangan bahan ajar materi trigonometri berbantuan software iMindMap pada siswa SMA. Al-Jabar: Jurnal Pendidikan Matematika, 7(1), 39-47. https://doi.org/10.24042/ajpm.v7i1.129

Rosdian, D. (2016). Pengembangan Perangkat Pembelajaran Matematika Model Role Playing Bernuansa Pendidikan Karakter pada Kemampuan Komunikasi Matematis Siswa. Seminar Nasional Matematika Dan Pendidikan Matematika (SNMPM) Universitas Swadaya Gunung Jati Cirebon, 440-460.

Sartika, N. S., \& Yulita, S. R. (2019). Penerapan bahan ajar trigamaster untuk meghindari mind in chaos siswa pada pokok bahasan trigonometri. SJME (Supremum Journal of Mathematics Education), 3(2), 78-84.

Sastrawati, E., \& Novallyan, D. (2017). Pengembangan Media Pembelajaran Interaktif Berbasis Android untuk Pemahaman Konsep Trigonometri. Jurnal IJER, 2(2), 72-76. http://edujurnal.iainjambi.ac.id/index.php/ijer IJER,

Suwito, A., \& Trapsilasiwi, D. (2016). Pengembangan model pembelajaran matematika SMP kelas VII berbasis kehidupan masyarakat JAWARA (Jawa dan Madura) di Kabupaten Jember. JIPM (Jurnal Ilmiah Pendidikan Matematika), 4(2), 79-84.

Zulkardi, \& Darmawijoyo. (n.d.). Pengembangan soal matematika model PISA pada konten quantity untuk mengukur kemampuan penalaran siswa sekolah menengah pertama. 